Article

\title{
Sustainability and Social Responsibility of Romanian Sport Organizations
}

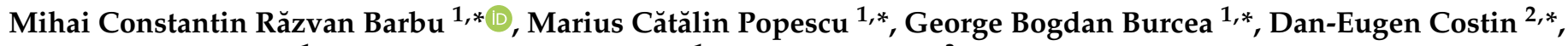 \\ Marian Gabriel Popa ${ }^{1, *}$, Leonardo-Daniel Păsărin ${ }^{1, *}$ and Ioan Turcu ${ }^{3, *}$
}

1 Department of Theory and Methodology of Motor Activities, University of Craiova, 200585 Craiova, Romania

2 Department of Individual Sports and Kinetotherapy, “Dunărea de Jos" University of Galați, 800008 Galati, Romania

3 Human Performance Department, Transilvania University of Brasov, 500036 Brașov, Romania

* Correspondence: mihai.barbu@edu.ucv.ro (M.C.R.B.); catalin.popescu@edu.ucv.ro (M.C.P.); george.burcea@edu.ucv.ro (G.B.B.); dan.costin@ugal.ro (D.-E.C.); gabriel.popa@edu.ucv.ro (M.G.P.); daniel.pasarin@edu.ucv.ro (L.-D.P.); ioan.turcu@unitbv.ro (I.T.); Tel.: +40-723-682-444 (M.C.R.B.)

check for

updates

Citation: Barbu, M.C.R.; Popescu,

M.C.; Burcea, G.B.; Costin, D.-E.;

Popa, M.G.; Păsărin, L.-D.; Turcu, I.

Sustainability and Social

Responsibility of Romanian Sport

Organizations. Sustainability 2022, 14,

643. https://doi.org/10.3390/

su14020643

Academic Editors: Pamela Wicker

and Shannon Kerwin

Received: 22 November 2021

Accepted: 5 January 2022

Published: 7 January 2022

Publisher's Note: MDPI stays neutral with regard to jurisdictional claims in published maps and institutional affiliations.

Copyright: () 2022 by the authors Licensee MDPI, Basel, Switzerland. This article is an open access article distributed under the terms and conditions of the Creative Commons Attribution (CC BY) license (https:/ / creativecommons.org/licenses/by/ $4.0 /)$.

\begin{abstract}
Sports organizations worldwide are discovering their power of influence over the fans and communities in which they operate, making more and more specialists and practitioners question these organizations' social responsibility and sustainable development. In sports organizations, although research is increasing, social responsibility and sustainability are topics that require special attention because sports organizations can instill values in a large number of people in different fields. In our paper, we propose a conceptual framework that allows for integrated research into corporate social responsibility (CSR) and the sustainability of sports organizations for sustainable management and identifies their influences on the overall performance. Based on the conceptual framework, we developed a scale for measuring sports organizations' social responsibility and sustainability, which we applied within sports organizations in Romania. The empirical study involved 280 respondents selected from the first two leagues of four sports areas (football, handball, volleyball, basketball). To support the conceptual framework, we used quantitative research methods in a transversal analysis: structural equation modeling and artificial neural network analysis. The conclusions of the empirical study in Romania show that social responsibility and sustainability are essential for the sustainable management of sports organizations and significantly influence the organization's overall performance. Among the pillars of sustainability, the social and human impact performance, given the specifics of sports organizations (involving large masses of people). Furthermore, legal and philanthropic responsibilities significantly influence CSR and organizational performance among CSR responsibilities.
\end{abstract}

Keywords: social responsibility; sustainability; sport organizations; performance

\section{Introduction}

In recent decades, issues of social responsibility of organizations towards society and their sustainable development, which ensure economic survival without affecting the natural and social environment, have been on the national and international agenda [1]. Social responsibility has become increasingly important for many organizations because there is pressure from the communities in which they operate and in society in general for the organization to assume legal, ethical, and philanthropic responsibilities in addition to economic ones [2]. As sports in clubs and leagues organized at the national and international level can remove many of the cultural, social, ethnic, and religious barriers, sports organizations have become an essential vector of influence in the field of social responsibility and sustainability [3]. Sports organizations managers are increasingly aware of the strategic importance of taking social responsibility and ensuring sustainability and 
their significant influences on overall performance. Sports organizations have many stakeholders, are very involved in the activities of organizations, and can influence the behavior of many people. Sports organizations managers have begun to understand the benefits of ethical, responsible, and sustainable behavior, which can lead to reduced operational costs, greater loyalty and increased fan and employee satisfaction, risks of sanctioning for lower laws and regulations, improved practices and activities, and public image [4]. Although the importance of social responsibility and ensuring sustainability in sports organizations has been recognized, there is little research on an integrated view of these areas, especially the influence on the organizations' overall performance.

Sustainable management combines the concepts of management with sustainable development. To have sustainable management, sports organizations must assume social responsibilities and get on the path of ensuring sustainability. This paper proposes an integrated framework for analyzing sports organizations' social responsibility and sustainability, providing a tool for measuring the effects of sports organizations' policies in these fields. From the beginning of the proposed theoretical framework, the measurement instrument reflects the responsibilities assumed within the CSR and the sustainability dimensions, as perceived by a category of main internal stakeholders-the employees of some sports clubs in Romania. The structure of the paper involves six sections. The Section 1 introduces the research topic, while the Section 2 reviews the literature. The Section 3 sets out the methodology and the tools used. The Sections 4 and 5 are an outline of the results, discussion, theoretical contributions, and practical implications The Section 6 provides conclusions and research limitations.

\section{Literature Review}

\subsection{Corporate Social Responsibility and Sustainability}

Since ancient times, individuals have been engaged in sports activities for social reasons, either individually or in a team [5]. However, in recent decades, sports organizations (clubs) have become more professional due to the transformation of sports into a mass phenomenon. As a result, sports organizations and economic activity have become an essential part of both the economy and society. Given the developments that characterize all economic organizations, sports organizations are no exception by engaging in sustainable and socially responsible business practices [6]. Moreover, for a long time, sports organizations have long been seen as social institutions and not economic ones, which makes stakeholders' expectations about responsible and sustainable behavior higher.

Due to the multidimensional concept of CSR, Carroll's model is one of the most commonly used models in the field of CSR. Carroll $[7,8]$ theorized the existence of four dimensions of social responsibility, adding to the economic one (the classical dimension that dominated capitalism until the emergence of theories on social responsibility and the role of stakeholders in the evolution of an organization), including legal, ethical, and philanthropic obligations [7]. He framed these responsibilities in a pyramid, placing at the core the economic responsibility on which all other responsibilities rest. Legal responsibilities imply the development of the organization's activities in compliance with the norms and regulations in the field. Ethical responsibilities involve imposing moral conduct and ethical behavior that consists of carrying out the organization's activities in compliance with values and codes that are self-imposed by the organization, based on the values within the communities in which it acts and society as a whole [9-11]. Finally, philanthropic responsibility involves voluntary efforts by which the organization returns some of the benefits it receives to the community.

The Triple Bottom Line concept developed by John Elkington [12] highlights organizational sustainability, which changed the sustainability paradigm for all organizations and institutions. The three dimensions defined by Elkington-people (social and human dimension), planet (environmental dimension), and profits (economic dimension) - have become a benchmark in research on ensuring sustainability, being the three pillars of sustainable approaches. Slaper and Hall [13] highlighted several challenges regarding ap- 
plying the Triple Bottom Line, including identifying appropriate indicators for assessing the three dimensions and calculating their contribution or impact on overall sustainability.

Recent research addressing the issue of social responsibility and sustainability at the level of sports organizations has shown that a responsible and sustainable approach has led to positive results for sports organizations [14-17]; these results were related in particular to improving the reputation and image of the organization $[18,19]$.

\subsection{CSR and Sustainability in Sport Organizations}

The limited literature has identified that environmental responsibilities influence the involvement of sports organizations in CSR [20-22], requiring a framework that incorporates the dimensions of sustainability into the sports organizations' social responsibilities. Kim et al. [21-25] suggest that involvement in CSR activities facilitates positive perceptions of an organization. The conclusions presented by [26] supported this suggestion; they further add to it by postulating that positive perceptions can lead to long-term benefits, such as attracting and retaining talented employees. Most studies show that some advantages of CSR are related to marketing, image, and reputation $[15,27]$. Although the benefits of CSR have been theorized and researched for a long time, there is still a significant gap in how involvement in social responsibility activities can also take on a sustainable dimension, with clear influences on the organization's overall performance.

Sports organizations have business models other than regular ones, so they require specific management techniques, with CSR in this area not making a distinctive note [28]. One of the specifics of sports activity organized in clubs and leagues is the irrational passion of fans for a sports team, which can lead them to adopt the values of that organization or their members (athletes). According to CSR and sustainable development, the paper proposed a tool for measuring social responsibility and sustainability in sports organizations [4,29-31].

Kolyperas et al. [32] pointed out a lack of vision on social responsibility and ensuring sustainability in sport. For the sports sector to integrate organically into general economic activity and society, sports organizations need to improve their understanding and involvement in social responsibility activities. Babiak and Wolfe [20] and the authors of [33,34] suggest that professional sports organizations cannot ignore social responsibility and sustainability, as they are vectors in all economic activities. Robertson et al. [35] suggest that, in addition to professional sports organizations, fan associations should put pressure on the responsible behavior of the organization and support the organization in its social actions. Breitbarth and Harris [29] show that these approaches can generate significant benefits for the sports organization and the community in which it operates. Bradish and Cronin and Fifka and Jaeger $[36,37]$ find that CSR effectively manages sustainable development.

Smith and Westerbeek [38] argue that stakeholders' perspectives are crucial to encourage social responsibility in sports organizations. Such an approach makes it possible to increase equity and diversity and improve social relations. Walters [39], based on the theoretical framework developed by Smith and Westerbeek [38], details the range of health, education, and social inclusion activities that each community sports trust is involved in, identifying the community sports trust model as an ideal vehicle for an organization to meet their social objectives. Zeimers et al. [40] relate organizational learning to social responsibility, revealing patterns of learning institutionalization for CSR in a particular European sport federated setting. Rowe et al. [41] propose community-oriented practices as a concept to describe the community-focused activities undertaken by professional sports teams, considering that CSR can be a vector for community development.

Starting from the results of previous research and the purpose of the paper, we formulated a set of three hypotheses based on the theoretical model applied in an empirical study:

Hypothesis 1 (H1). Of the responsibilities at the CSR level, ethical and philanthropic responsibilities have a positive effect on CSR in the perception of the sports organizations' employees. 
Hypothesis 2 (H2). In the perception of sports organizations' employees, the social and human dimensions have a positive effect on sustainability.

Hypothesis 3 (H3). Both constructs (social responsibility and sustainability) positively influence the overall performance of sports organizations' sustainability.

\section{Methodology}

\subsection{Research Design}

The paper aims to identify the relationships between the social responsibility of sports organizations and the dimensions of the Triple Bottom Line in sustainability policies and their influence on the overall performance of the sports organization. Figure 1 shows the conceptual model of the research.

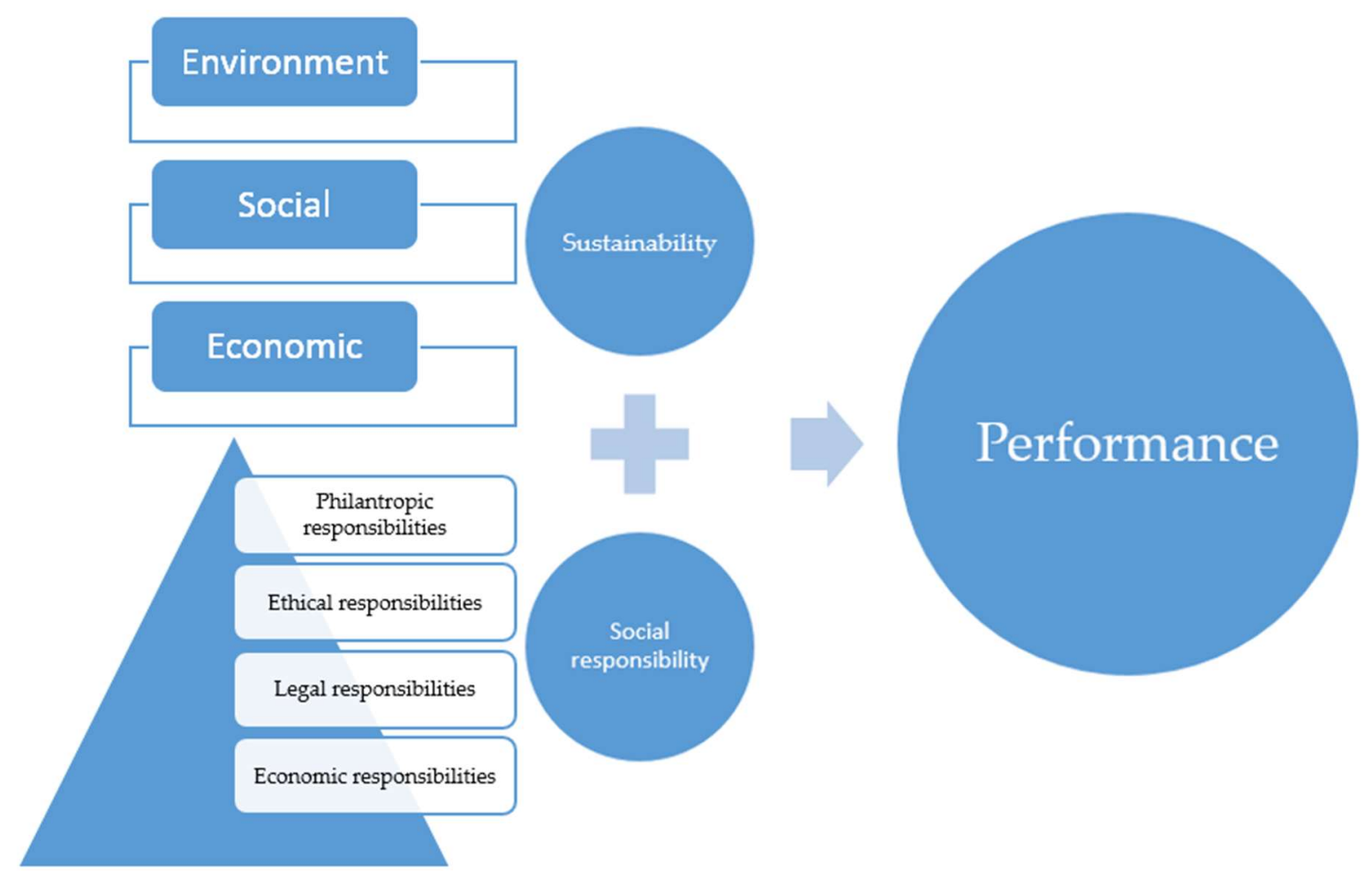

Figure 1. Conceptual framework of research on sustainability and social responsibility of sports organizations. Source: own design.

A quantitative study analyzed and evaluated the responsibilities within CSR and the dimensions of sustainability in sports organizations. After the research, based on which the questionnaire was built and formulated hypotheses, we conducted an empirical study using quantitative methods on sports organizations in Romania.

\subsection{Measures}

The evaluation tool is a questionnaire based on results of other empirical studies on CSR and sustainability [4,42-45]. The questionnaire containing 30 items addresses an essential category of stakeholders for any organization, especially critical to sports organizations: employees. Of the 30 items, 4 items represent sport-related variables: sports area (football, handball, volleyball, and basketball), the league in which the sports club is located (first or second), the type of employee activity (sports or support activities), and the position (manager or subordinate). The other 26 items include CSR responsibilities (economic, legal, ethical, and philanthropic), the dimensions of sustainability (economic, environmental, social, and human), and the overall performance of the sports organization. In addition, we added three aggregate variables (corporate social responsibility and overall 
performance). We calculated corporate social responsibility (CSR) and sustainability (S) as averages of the items allocated to corporate social responsibility and sustainability, respectively. The overall performance of sports organizations is a hybrid construct of employee perception (measured on an increasing scale from 1 to 25), the organization's financial situation, the position in the league standings, and the number of declared fans of the team managed by the sports organization. Data collected from employees on their perception of performance were summed with points awarded (maximum 25 points) by researchers based on data collected about sports organizations. Appendix A (Table A1) presents the questionnaire structure.

We performed another test by calculating Guttman's Lambda coefficient $(\lambda)$ to test the reliability. The values of $\lambda_{2}$ (a measure similar with Cronbach's alpha) and $\lambda_{3}$ are the most used in performing statistical reliability tests [45]. Table 1 shows the values recorded by Guttman's Lambda coefficient $(\lambda)$ for the 29 items.

Table 1. Guttman's Lambda $(\lambda)$ values.

\begin{tabular}{cc}
\hline Coefficient & Value \\
\hline Lambda 1 & 0.837 \\
Lambda 2 & 0.902 \\
Lambda 3 & 0.867 \\
Lambda 4 & 0.810 \\
Lambda 5 & 0.916 \\
Lambda 6 & - \\
Items & 29 \\
\hline
\end{tabular}

Both values recorded by Gutmann's coefficients $\lambda_{2}-0.902$ and $\lambda_{3}-0.867$, respectively) show good reliability of the variables that make up the questionnaire, allowing for the recording of relevant and replicable results [45]. Table 2 shows the detailed reliability for each item.

Table 2. Detailed reliability scores.

\begin{tabular}{lcccc}
\hline Scale Mean If & $\begin{array}{c}\text { Scale Variance } \\
\text { Item Deleted }\end{array}$ & $\begin{array}{c}\text { Corrected } \\
\text { Item-Total } \\
\text { Correlation }\end{array}$ & $\begin{array}{c}\text { Cronbach's Alpha } \\
\text { If Item Deleted }\end{array}$ \\
\hline EcR1 & 191.80 & 226.626 & 0.585 & 0.861 \\
EcR2 & 191.85 & 239.927 & -0.087 & 0.871 \\
EcR3 & 192.20 & 227.939 & 0.434 & 0.863 \\
EcR4 & 191.95 & 229.038 & 0.558 & 0.862 \\
EcR5 & 191.55 & 233.583 & 0.263 & 0.866 \\
LeR1 & 192.00 & 217.576 & 0.696 & 0.856 \\
LeR2 & 191.85 & 231.038 & 0.298 & 0.865 \\
LeR3 & 192.20 & 237.232 & 0.090 & 0.868 \\
EtR1 & 191.45 & 233.785 & 0.247 & 0.866 \\
EtR2 & 192.25 & 233.826 & 0.196 & 0.867 \\
EtR3 & 191.85 & 227.098 & 0.689 & 0.861 \\
EtR4 & 192.10 & 224.636 & 0.689 & 0.859 \\
EtR5 & 191.75 & 237.967 & 0.026 & 0.869 \\
PhR1 & 192.00 & 215.152 & 0.743 & 0.855 \\
PhR2 & 192.15 & 215.482 & 0.870 & 0.853 \\
PhR3 & 192.35 & 230.028 & 0.560 & 0.863 \\
PhR4 & 192.10 & 230.899 & 0.293 & 0.865 \\
PhR5 & 192.25 & 226.755 & 0.476 & 0.862 \\
EnR1 & 192.90 & 222.919 & 0.577 & 0.860 \\
EnR2 & 191.90 & 232.616 & 0.217 & 0.866 \\
EnR3 & 192.25 & 237.260 & 0.082 & 0.868 \\
EnR4 & 192.35 & 230.028 & 0.560 & 0.863 \\
\hline
\end{tabular}


Table 2. Cont.

\begin{tabular}{ccccc}
\hline & $\begin{array}{c}\text { Scale Mean If } \\
\text { Item Deleted }\end{array}$ & $\begin{array}{c}\text { Scale Variance } \\
\text { If Item Deleted }\end{array}$ & $\begin{array}{c}\text { Corrected } \\
\text { Item-Total } \\
\text { Correlation }\end{array}$ & $\begin{array}{c}\text { Cronbach's Alpha } \\
\text { If Item Deleted }\end{array}$ \\
\hline SoR1 & 192.20 & 215.515 & 0.852 & 0.854 \\
SoR2 & 192.75 & 216.553 & 0.827 & 0.854 \\
SoR3 & 192.30 & 225.465 & 0.524 & 0.861 \\
SoR4 & 192.40 & 212.162 & 0.848 & 0.852 \\
P & 115.35 & 138.513 & 0.711 & 0.909 \\
CSR & 188.20 & 224.202 & 0.385 & 0.863 \\
S & 188.35 & 208.210 & 0.774 & 0.851 \\
\hline
\end{tabular}

The factor analysis highlighted six components in which the items that characterize the six types of responsibilities (economic, legal, ethical, philanthropic, environmental, social, and human). Table 3 shows the communalities and the rotated component matrix, built using the Varimax rotation method with Kaiser normalization (11 iterations in the rotation process).

Table 3. Rotated component matrix.

\begin{tabular}{|c|c|c|c|c|c|c|c|c|}
\hline \multirow{2}{*}{\multicolumn{3}{|c|}{ Communalities }} & \multicolumn{6}{|c|}{ Rotated Component Matrix } \\
\hline & & & \multicolumn{6}{|c|}{ Component } \\
\hline & Initial & Extraction & 1 & 2 & 3 & 4 & 5 & 6 \\
\hline EcR1 & 1.000 & 0.873 & 0.948 & & & & & \\
\hline EcR2 & 1.000 & 0.962 & 0.923 & & & & & \\
\hline EcR3 & 1.000 & 0.974 & 0.907 & & & & & \\
\hline EcR4 & 1.000 & 0.878 & 0.809 & & & & & \\
\hline EcR5 & 1.000 & 0.827 & 0.678 & 0.522 & & & & \\
\hline LeR1 & 1.000 & 0.944 & 0.600 & 0.592 & & & & 0.419 \\
\hline LeR2 & 1.000 & 0.875 & & 0.936 & & & & \\
\hline LeR3 & 1.000 & 0.955 & & 0.900 & & & & \\
\hline EtR1 & 1.000 & 0.696 & 0.387 & 0.798 & & & & 0.357 \\
\hline EtR2 & 1.000 & 0.852 & 0.499 & 0.643 & & & 0.441 & \\
\hline EtR3 & 1.000 & 0.923 & & & -0.872 & & & -0.361 \\
\hline EtR4 & 1.000 & 0.755 & & & -0.859 & & 0.376 & \\
\hline EtR5 & 1.000 & 0.951 & 0.490 & 0.478 & 0.696 & & & \\
\hline PhR1 & 1.000 & 0.944 & 0.490 & 0.478 & 0.696 & & & \\
\hline PhR2 & 1.000 & 0.966 & 0.551 & 0.430 & 0.572 & & & \\
\hline PhR3 & 1.000 & 0.987 & & & & -0.853 & 0.323 & \\
\hline PhR4 & 1.000 & 0.752 & & & & -0.714 & & \\
\hline PhR5 & 1.000 & 0.958 & 0.575 & & & 0.645 & & \\
\hline EnR1 & 1.000 & 0.927 & 0.630 & & & 0.639 & & \\
\hline EnR2 & 1.000 & 0.945 & 0.341 & & -0.540 & 0.596 & & \\
\hline EnR3 & 1.000 & 0.903 & 0.460 & & -0.493 & 0.545 & & 0.433 \\
\hline EnR4 & 1.000 & 0.987 & & & & & 0.828 & \\
\hline SoR1 & 1.000 & 0.932 & & 0.366 & & & -0.766 & \\
\hline SoR2 & 1.000 & 0.918 & & & -0.464 & & 0.661 & \\
\hline SoR3 & 1.000 & 0.931 & & 0.478 & & & & 0.726 \\
\hline SoR4 & 1.000 & 0.870 & & & 0.321 & & -0.475 & 0.706 \\
\hline
\end{tabular}

\subsection{Selected Sample}

To carry out the research, we selected the sports clubs from Romania from the most important sports areas. The researched population consists of all the employees of these sports clubs operating in the first and second leagues in selected sports areas. The sampling method was stratified sampling. For stratification, we used demographic and sport related variables: sports area, league, type of activity, and position. Within the layers, we used random sampling. According to the defined demographic and sport related variables, 
the initial sample was composed of 294 individuals-employees of sports organizations. However, from the questionnaires received, we removed 14 due to their partially filled questionnaire (more than a quarter of the questions remained unanswered), resulting in a sample of 280 respondents. Therefore, the sample follows the structure of the population demographic and sport-related criteria; the sampling error is $4.3 \%$ with a $95 \%$ level of confidence. Table 4 shows the sample frequencies based on demographic and sportrelated variables.

Table 4. Descriptive statistics.

\begin{tabular}{cccccc}
\hline Area & Frequency & Percent & Age & Frequency & Percent \\
\hline Football & 84 & 30.0 & $18-30$ years & 68 & 24.0 \\
Handball & 70 & 25.0 & $31-45$ years & 94 & 34.0 \\
Volleyball & 70 & 25.0 & $46-60$ years & 95 & 34.0 \\
Basketball & 56 & 20.0 & over 60 years & 23 & 8.0 \\
Total & 280 & 100.0 & & & \\
\hline League & Frequency & Percent & Gender & Frequency & Percent \\
\hline 1 & 126 & 45.0 & Male & 114 & 76.0 \\
\hline 2 & 154 & 55.0 & Female & 66 & 24.0 \\
\hline Total & 280 & 100.0 & & & \\
\hline Activity & Frequency & Percent & Position & Frequency & Percent \\
\hline Sport & 84 & 30.0 & Managerial & 70 & 25.0 \\
Support & 196 & 70.0 & Subordination & 210 & 75.0 \\
Total & 280 & 100.0 & & 280 & 100.0 \\
\hline
\end{tabular}

Respondents assessed their perceptions of CSR responsibilities and the dimensions of sustainability within the organization where they are employed. We measured all items using a Likert scale with five response options (1-total disagreement with the allegation, 2-partial disagreement with the allegation, 3-neutral position on the allegation, 4-partial agreement with the allegation, and 5-complete agreement with the allegation).

\subsection{Empirical Analysis}

To establish the relationships between the variables and the selected influences, we used quantitative research methods in a transversal analysis to test the hypotheses articulated based on the literature review and our observations in sports organizations. The methods used in the research were structural equation modeling and analysis of artificial neural network (to identify the influences in a multivariable set), which are methods used by other authors to determine the influences of the independent variables on dependent variables [10,46-48]. We used structural equation modeling to test substantive theories, which infers observable and latent variables [46-50]. Latent variables cannot be measured directly by a visible variable, making it necessary to consider structural equation modeling [51].

Structural equation modeling is based on Equation (1) [52]:

$$
\eta=\mathrm{B} \eta+\Gamma \xi+\zeta
$$

where:

$\eta, \xi$-endogenous and exogenous latent variables;

$\mathrm{B}$ - matrix of regression coefficients relating the latent endogenous variables to each other;

$\Gamma-$ matrix of regression coefficients relating the endogenous variables to exogenous variables;

$\zeta$-disturbance. 
Artificial neural network analysis uses a multilayer perceptron (MLP) [53], with Formula (2):

$$
\mathrm{y}=\left(\sum_{\mathrm{i}=1}^{\mathrm{n}} \mathrm{w}_{\mathrm{i}} \mathrm{x}_{\mathrm{i}}+\mathrm{b}\right)=\varphi\left(\mathrm{W}^{\mathrm{T}} \mathrm{X}+\mathrm{b}\right)
$$

where:

b-bias;

$\mathrm{w}, \mathrm{x}$-vectors of weights and inputs;

$\varphi$-activation function.

\section{Empirical Results}

To test the hypotheses established starting from the research purpose, we used structural equation modeling (SEM) applied to the data collected from the sample selected using the SmartPLS v3.0 software. The conceptual model applied to the collected data is shown in Figure 2.

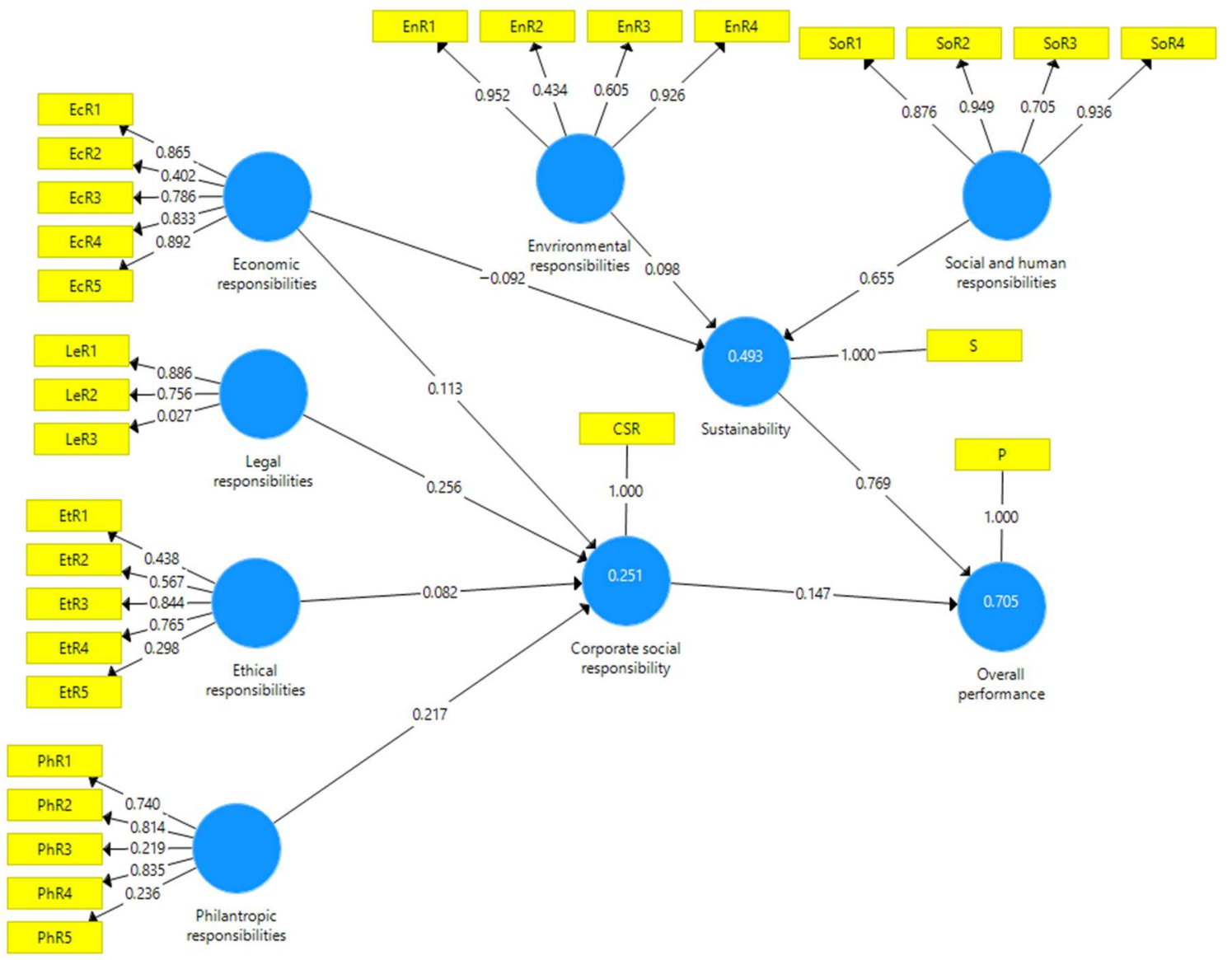

Figure 2. The conceptual framework applied to collected data. Source: developed based on collected data using SmartPLS v3.0.

To increase the model's validity and reliability, those items with a load of less than 0.7 must be removed [54]. Figure 3 shows the improved model by eliminating items that reduce validity and reliability. 


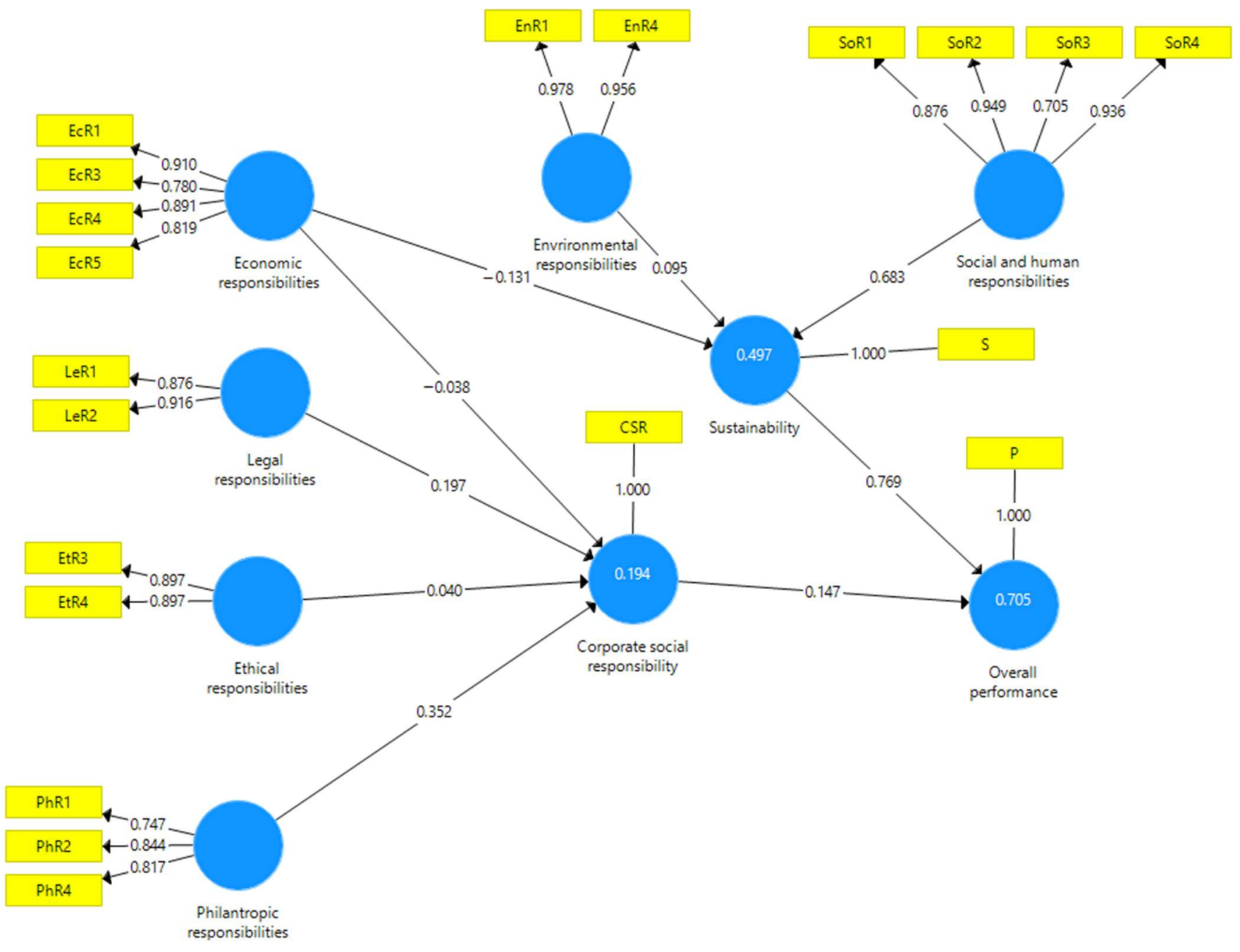

Figure 3. Improved applied model. Source: developed based on collected data using SmartPLS v3.0.

Table 5 shows the validity and reliability of the model after eliminating the items that were not compatible with the other questionnaire items. Again, one can observe the model's high validity and reliability: Cronbach's alpha coefficients are all over 0.7, composite reliability recorded values over 0.8 , and average variance extracted records values over 0.6 [55].

Table 5. Model reliability and validity.

\begin{tabular}{lcccc}
\hline & $\begin{array}{c}\text { Cronbach's } \\
\text { Alpha }\end{array}$ & rho_A & $\begin{array}{c}\text { Composite } \\
\text { Reliability }\end{array}$ & $\begin{array}{c}\text { Average } \\
\text { Variance } \\
\text { Extracted }\end{array}$ \\
\hline Corporate social responsibility (CSR) & 1.000 & 1.000 & 1.000 & 1.000 \\
Economic responsibilities (EcR) & 0.875 & 0.904 & 0.913 & 0.725 \\
Environmental responsibilities (EnR) & 0.933 & 1.014 & 0.966 & 0.935 \\
Ethical responsibilities (EtR) & 0.758 & 0.758 & 0.892 & 0.805 \\
Legal responsibilities (LeR) & 0.757 & 0.774 & 0.891 & 0.803 \\
Overall performance (P) & 1.000 & 1.000 & 1.000 & 1.000 \\
Philanthropic responsibilities (PhR) & 0.759 & 0.736 & 0.845 & 0.646 \\
Social and human responsibilities (SoR) & 0.896 & 0.952 & 0.926 & 0.761 \\
Sustainability (S) & 1.000 & 1.000 & 1.000 & 1.000 \\
\hline
\end{tabular}


The evaluation of discriminant validity is an essential condition for the model validity. Table 6 shows the Fornell-Larcker matrix, in which the main diagonal is the square root of the AVE. Below are the values of the inter-correlation coefficients of the latent variables.

Table 6. Assessment of discriminant validity using the Fornell-Larcker criterion.

\begin{tabular}{ccccccccc}
\hline & CSR & EcR & EnR & EtR & LeR & P & PhR & SoR \\
\hline CSR & 1.000 & & & & & & & \\
EcR & 0.269 & 0.852 & & & & & & \\
EnR & -0.092 & 0.197 & 0.967 & & & & & \\
EtR & 0.319 & 0.442 & 0.583 & 0.897 & & & & \\
LeR & 0.266 & 0.399 & 0.528 & 0.364 & 0.896 & & & \\
P & 0.464 & 0.444 & 0.298 & 0.710 & 0.291 & 1.000 & & \\
PhR & 0.394 & 0.598 & 0.273 & 0.635 & 0.196 & 0.625 & 0.804 & \\
SoR & 0.240 & 0.504 & 0.763 & 0.772 & 0.583 & 0.634 & 0.703 & 0.872 \\
S & 0.413 & 0.233 & 0.591 & 0.722 & 0.435 & 0.829 & 0.424 & 0.690 \\
\hline
\end{tabular}

Table 7 shows path coefficients to illustrate the significance of the established influences between the model variables.

Table 7. Path coefficients.

\begin{tabular}{|c|c|c|c|c|}
\hline & Path & Coefficients & T-Statistics & $p$-Values \\
\hline & $\begin{array}{c}\text { Economic responsibilities -> Corporate } \\
\text { social responsibility }\end{array}$ & -0.033 & 0.293 & 0.770 \\
\hline \multirow{3}{*}{$\mathrm{H} 1$} & $\begin{array}{c}\text { Legal responsibilities -> Corporate social } \\
\text { responsibility }\end{array}$ & 0.197 & 1.303 & 0.071 \\
\hline & $\begin{array}{c}\text { Ethical responsibilities }->\text { Corporate social } \\
\text { responsibility }\end{array}$ & 0.040 & 0.366 & 0.714 \\
\hline & $\begin{array}{c}\text { Philanthropic responsibilities -> Corporate } \\
\text { social responsibility }\end{array}$ & 0.352 & 2.954 & 0.003 \\
\hline \multirow{3}{*}{$\mathrm{H} 2$} & Economic responsibilities $->$ Sustainability & -0.131 & 1.694 & 0.091 \\
\hline & $\begin{array}{c}\text { Environmental responsibilities -> } \\
\text { Sustainability }\end{array}$ & 0.095 & 1.133 & 0.237 \\
\hline & $\begin{array}{l}\text { Social and human responsibilities -> } \\
\text { Sustainability }\end{array}$ & 0.633 & 7.842 & 0.000 \\
\hline \multirow[t]{2}{*}{$\mathrm{H} 3$} & Sustainability -> Overall performance & 0.769 & 19.352 & 0.000 \\
\hline & $\begin{array}{c}\text { Corporate social responsibility -> Overall } \\
\text { performance }\end{array}$ & 0.147 & 2.566 & 0.011 \\
\hline
\end{tabular}

Studying the data from Table 7 and Figure 3, we see that the H1 hypothesis is partially confirmed. Employees of sports organizations included in the research sample consider that philanthropic and legal responsibilities are the most important in terms of social responsibility by the organization. The research of the $\mathrm{H} 2$ hypothesis led to its confirmation. In the perception of the sports organizations' employees, the most important dimension of sustainability is the social and human one, which was to be expected, given the subjectivism of the respondents. The third hypothesis (H3) is also confirmed. The two constructs (social responsibility and sustainability) positively influence the overall performance of sports organizations, sustainability being more critical in the perception of sports organizations' employees.

To consolidate the research results regarding the influence of social responsibility and sustainability on the total performance of sports organizations, we applied an analysis of artificial neural networks. The model used was MLP, which allows for the establishment of relationships between input variables and output variables through a hidden layer. In our research, we used the two constructs (social responsibility and sustainability) as input variables, the output variable the overall performance of sports organizations. The hidden layer is represented by the perception of sports organizations' employees. The model 
also involves external factors acting through biases on the hidden and output layers. The hyperbolic tangent type activates the hidden and output layers from the upstream variables. The formula for this type of function is as follows (Formula (3)):

$$
f(n)=\frac{e^{n}-e^{-n}}{e^{n}+e^{-n}}=\frac{e^{2 n}-1}{e^{2 n}+1}
$$

$\mathrm{n}$-input variable;

$\mathrm{f}(\mathrm{n})$ - output variable.

Figure 4 shows the diagram of the relationships established in the MLP model between the input and output variables.

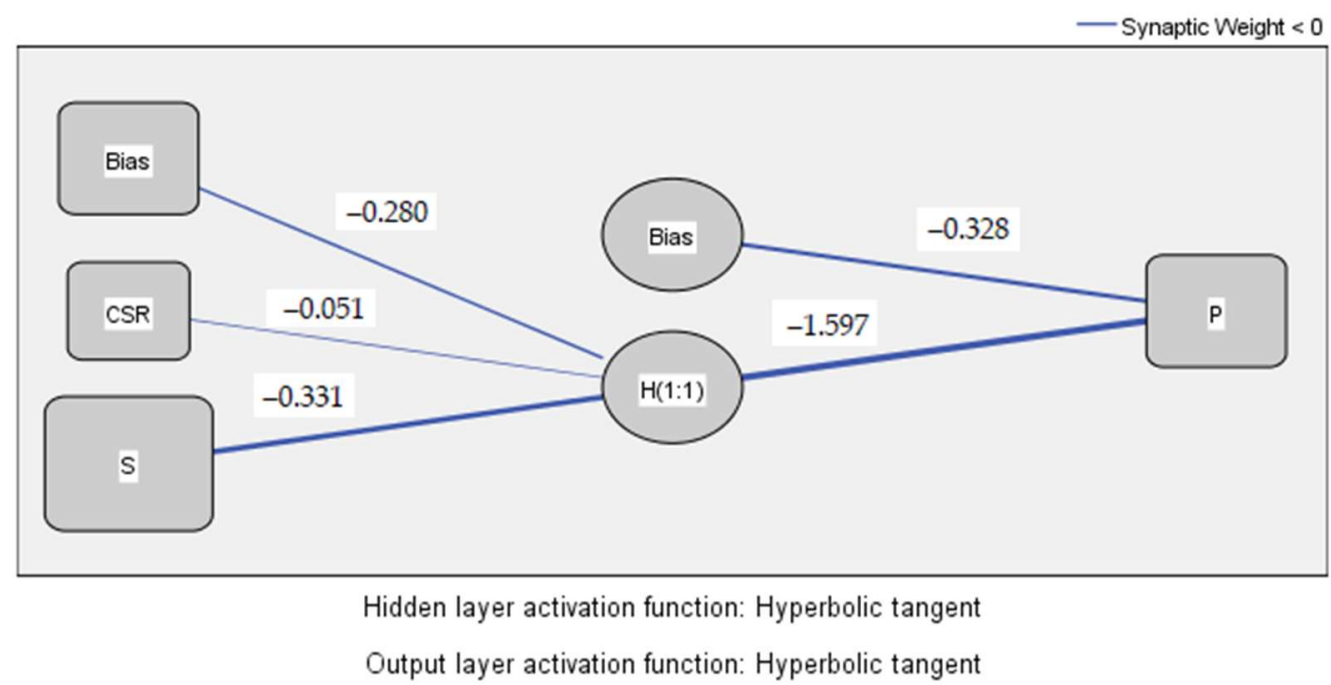

Figure 4. MLP model on overall performance. Source: developed using SPSS v.20.

The analysis of Figure 4 and the data in Table 8 reveals the existence of significant influences of social responsibility and sustainability on the overall performance of sports organizations. Therefore, the H3 hypothesis is also confirmed. A decrease in the level of social responsibility and ensuring sustainability has a strong influence in decreasing the performance of sports organizations. The bias on the hidden layer has a significant influence, indicating the impact of external factors of the model on the perception of sports organizations' employees. The bias on the exit layer has a relatively small influence compared to the influence of the hidden layer, highlighting the importance of the perception of sports 'organizations' employees in terms of social responsibility and ensuring organizational sustainability.

Table 8. The predictors of the MLP model.

\begin{tabular}{cccc}
\hline & & \multicolumn{2}{c}{ Predicted } \\
\cline { 3 - 4 } Predictor & & Hidden Layer 1 & Output Layer \\
\cline { 3 - 4 } & & H(1:1) & Performance \\
\cline { 3 - 4 } Input Layer & (Bias) & -0.280 & \\
& CSR & -0.051 & -0.328 \\
& S & -0.331 & -1.597 \\
\hline \multirow{2}{*}{ Hidden Layer 1 } & (Bias) & & \\
& H(1:1) & & \\
\hline
\end{tabular}

Figure 5 shows the absolute and normalized importance calculated for the input variables in terms of the influence on the output variable through the hidden layer. 


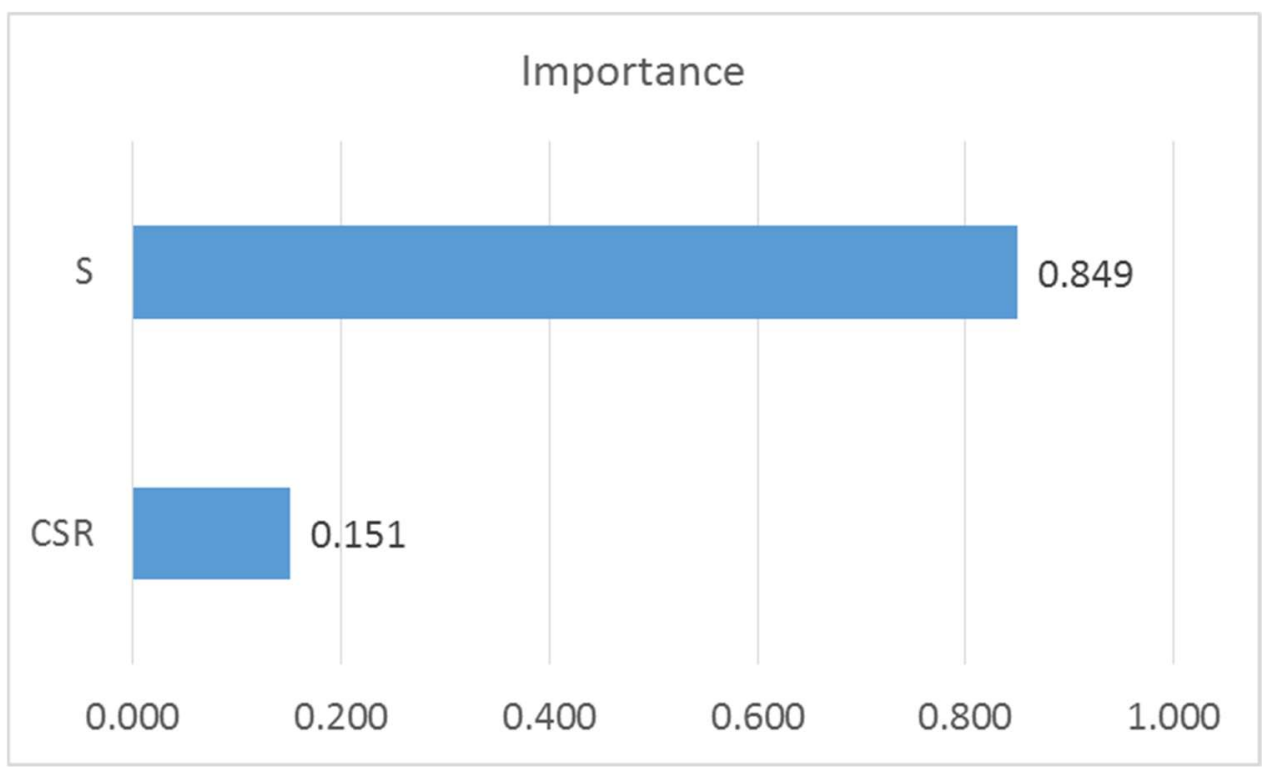

Figure 5. Importance of variables from MLP model. Source: developed using SPSS v.20.

Both constructs (social responsibility with absolute importance of 0.151 and relative importance of $17.7 \%$ and sustainability with the fundamental importance of 0.849 and relative importance of $100 \%$ ) have a positive influence on the overall performance of sports organizations, with sustainability being more critical in the perception of sports organizations' employees.

\section{Discussion}

Many people on the planet consider sports to be a part of their lives [56]. Therefore, sports organizations can use their abilities to influence a large mass of people to solve several social problems, thus contributing to the welfare and well-being of society [57]. Research on CSR social responsibility initiatives has focused on CSR initiatives implemented by local [51,58] or national [59] leagues and on the benefits of the communities where these sports activities occur. Smith and Westerbeek [38] support the encouragement of implementing social responsibility in sports organizations, giving the possibility to increase equity and diversity and improve social relations. Zeimers et al. [39] propose that sports organizations use organizational learning to increase social responsibility. Accepting the environmental dimension of sustainability by the employees of sports organizations aligns with previous research findings $[20,38-40,50]$. The changing values determine the emphasis on care for the environment in sports organizations in society and the increased commitment of employees to the expectations of several external stakeholders. Caring for the environment can also bring economic benefits, strengthening legitimacy [42]. In a similar way to [4], we combined the model of sustainable development offered by the Triple Bottom Line approach with its multidimensional model [17] on social responsibility. The ultimate goal of improving social responsibilities and a sustainable approach to performance is to increase profitability and ensure sustainability, making significant contributions to society [60]. Rowe et al. [41] propose community-focused activities undertaken by professional sports teams to turn CSR into a vector for community development.

Additionally, following the research, we found that the support of cultural and social events in the community, support for NGOs, contribution to health and well-being in the community, and solving social problems are essential factors in the philanthropic responsibility of sports organizations. Furthermore, as [61] charitable events note, CSR is the most popular practice in professional sports organizations. These findings are in line with the results obtained by $[4,56]$, according to which sports organizations are already dedicated to promoting community activities that have a positive impact on society. 
Walters [39] also identified the community sports trust model as an ideal vehicle for an organization to meet its social objectives.

Social responsibility and sustainability initiatives are essential strategic components used by organizations to improve their image and reputation. Compliance with the rules, regulations, and legal norms provides stability and credibility, making legal responsibilities important in employees' perception of CSR. Ensuring that operation meets all legal standards seems to be an essential factor in the legal obligation of sports teams. Rules and regulations defend the majority's interests, respecting them and ensuring all organizations' smooth running $[17,18]$. Regarding sustainability and environmental protection, the attempt to use renewable resources for sustainable development are essential factors in guaranteeing the solid sustainability of sports organizations. Our research results are in line with findings from other studies $[4,43,44]$, highlighting the relationship between sports and the environment.

\subsection{Theoretical Implications}

Sustainable management of sports organizations can be achieved by assuming social responsibilities and ensuring sustainable development. Implementing social responsibility and sustainability in sports organizations allows them to return some of their benefits to the community. Using sports as a means to increase social responsibility and sustainability is an opportunity for both responsible sports organizations and those in other fields who use sports in their efforts to contribute to communities.

Our paper aimed to provide an integrated conceptual model for studying the assumption of responsibilities in CSR and the application of the dimensions of sustainability in sports organizations. This model superimposes social responsibilities and sustainability dimensions providing a theoretical framework for their combined implementation. The results of this paper support the findings of other researchers on the importance of taking social responsibility and ensuring the sustainability of sports organizations $[24,38,59,61]$. However, more research is needed on how CSR and sustainability can be applied in an integrated way, especially the effects on overall performance, leading to emulation among the employees of sports organizations.

\subsection{Practical Implications}

Managers of sports organizations can carry out sustainable management if they are aware of the assumption of social responsibilities (economic, legal, ethical, and philanthropic) and the need to implement the three dimensions of sustainability: economic, social, and environmental. Although corporate social responsibility is an accepted concept in most corporations, the social responsibilities of sports organizations are underdeveloped. This paper aims to make these responsibilities transparent and superimpose them on sustainability dimensions. Furthermore, sport is a social activity that attracts many individuals to propose a change in communities and contribute to the sustainable development of society. Therefore, corporate managers and sports managers can combine economic, social, and environmental responsibilities by maximizing the social benefits of sustainable management to society.

To conduct the research effectively, we developed a tool for measuring and evaluating CSR and sustainability, which we applied within sports organizations in various areas and leagues in Romania. One of the results of this study is the confirmation of the multidimensional nature of a sports organization's social responsibility and sustainability, in line with the results of previous research [4,61-63]. The study was conducted on the perception of employees of sports organizations, the most important internal stakeholder. Their perceptions show that the most critical responsibilities of a sports organization are legal and philanthropic, and the dimensions of sustainability, both social and human, are particularly distinct. This result is also affected by a single category of stakeholders (employees). Therefore, managers of sports organizations can use the tool to increase the degree 
of commitment of employees in the field of social responsibility and their involvement in ensuring the organization's sustainability, as the basis of sustainable management.

\section{Conclusions}

More and more organizations operating in the world of sport are addressing various forms of social responsibility in recent decades. Managers of sports organizations find resources for these actions in financial benefits [64], improving image and reputation [56,57], fan loyalty [57,65], and attracting potential talent [66]. In addition, sports organizations have deep roots in their communities, which has led them to adopt CSR as a standard practice $[67,68]$. However, social responsibility is an asset for the organization if management communicates CSR actions effectively to inform stakeholders and influence their perceptions $[57,69]$.

The paper seeks to provide a theoretical model and a practical tool for measuring and evaluating the social responsibility and sustainability of sports organizations. However, this paper has some limitations, which can be opportunities for future research. First, the applied research tool (questionnaire) included 30 items established following the literature analysis. Of the 30 items, we removed 5 items after studying the validity of the sample selected from the employees. Considering several categories of stakeholders in future research will increase the validity and reliability of the proposed instrument, allowing for more detailed and more accurate results. Secondly, the collection of data in only four areas of sport and two categories of leagues does not allow for the extrapolation of the results of this research to the level of all sports organizations. Future studies on representativeness criteria are needed to enable such an extrapolation of results. Thirdly, a limitation derived from this research's cross-cutting nature, which does not assess employees' perceptions of differences in different periods. A future direction of research may be to conduct a longitudinal study. Therefore, it would be interesting to repeat the study once the sports industry has recovered. In conclusion, the paper provides a generous research framework that can lay the groundwork for further investigations to confirm the results and expand the conceptual framework on social responsibility and the sustainability of sports organizations.

Author Contributions: All authors of the paper have an equal contribution. Conceptualization, formal analysis, investigation, methodology, validation, writing—original draft, and writing—review and editing: M.C.R.B., M.C.P., G.B.B., D.-E.C., M.G.P., L.-D.P. and I.T. All authors have read and agreed to the published version of the manuscript.

Funding: This research received no external funding.

Institutional Review Board Statement: Not applicable.

Informed Consent Statement: Not applicable.

Data Availability Statement: Not applicable.

Conflicts of Interest: The authors declare no conflict of interest. 


\section{Appendix A}

Table A1. The structure of the questionnaire.

\begin{tabular}{|c|c|c|}
\hline Construct & Variable & Code \\
\hline \multirow{4}{*}{ Sport-related variables } & Area & Area \\
\hline & League & League \\
\hline & Activity & Act \\
\hline & Position & Pos \\
\hline \multirow{5}{*}{ Economic responsibilities } & Fans' satisfactions & EcR1 \\
\hline & Fans' increasing actions & EcR2 \\
\hline & Long-term success & EcR3 \\
\hline & Cost management & EcR4 \\
\hline & Maximize profits & EcR5 \\
\hline \multirow{3}{*}{ Legal responsibilities } & Compliance with the law & LeR1 \\
\hline & Compliance with the rules and regulation & LeR2 \\
\hline & Respecting the rights of fans & LeR3 \\
\hline \multirow{5}{*}{ Ethical responsibilities } & Fair play in the competitions & EtR1 \\
\hline & Compliance with the ethical values & EtR2 \\
\hline & Accountability to fans' needs and demands & EtR3 \\
\hline & Data protection and privacy & EtR4 \\
\hline & Avoiding unethical behavior & EtR5 \\
\hline \multirow{5}{*}{ Philanthropic responsibilities } & Supporting community events & PhR1 \\
\hline & Supporting NGOs & PhR2 \\
\hline & Supporting community health and wellness & PhR3 \\
\hline & Helping social cases & $\mathrm{PhR} 4$ \\
\hline & Improving the community welfare & PhR5 \\
\hline \multirow{4}{*}{ Environmental responsibilities } & Protect the environment & EnR1 \\
\hline & Environmental awareness training for fans & EnR2 \\
\hline & Using of renewable resources & EnR3 \\
\hline & Sustainable development & EnR4 \\
\hline \multirow{4}{*}{ Social responsibilities } & Employee engagement & SoR1 \\
\hline & Gender and diversity & SoR2 \\
\hline & Human rights & SoR3 \\
\hline & Labor standards & SoR4 \\
\hline Overall performance & Performance & $\mathrm{P}$ \\
\hline
\end{tabular}

\section{References}

1. Vaaland, T.I.; Heide, M.; Gronhaug, K. Corporate social responsibility: Investigating theory and research in the marketing context. Eur. J. Mark. 2008, 42, 927-953. [CrossRef]

2. Anderson, J.W. Corporate Social Responsibility; Greenwood Press: Westport, CT, USA, 1989.

3. Giroux, M.; Pons, F.; Mourali, M. Is CSR Important for All Types of Fans?: The Value of Corporate Social Responsibility in Sport. In Marketing Dynamism \& Sustainability: Things Change, Things Stay the Same, Proceedings of the 2012 Academy of Marketing Science (AMS) Annual Conference, New Orleans, LA, 15-20 May 2012; Robinson, J.L., Ed.; Springer International Publishing: Cham, Switzerland, 2015; pp. 497-500. [CrossRef]

4. Montazeri, A.; Talebpour, M.; Andam, R.; Kazemnejad, A. Measuring Corporate Social Responsibility in Sport Industry: Development and Validation of Measurement Scale. Ann. Appl. Sport Sci. 2017, 5, 97-114. [CrossRef]

5. Reid, H.L. Athletics and Philosophy in the Ancient World Contests of Virtue; Routledge Taylor and Francis: New York, NY, USA, 2011; ISBN 9781315874524

6. Walzel, S.; Robertson, J.; Anagnostopoulos, C. Corporate social responsibility in professional team sports organizations: An integrative review. J. Sport Manag. 2018, 32, 511-530. [CrossRef]

7. Carroll, A.B. A three-dimensional conceptual model of corporate performance. Acad. Manag. Rev. 1979, 4, 497-505. [CrossRef]

8. Carroll, A.B. Corporate Social Responsibility: Evolution of a Definitional Construct. Bus. Soc. 1999, 38, 268-295. [CrossRef]

9. Lantos, G.P. The boundaries of strategic corporate social responsibility. J. Consum. Mark. 2001, 18, 595-632. [CrossRef] 
10. Nicolescu, M.M.; Vărzaru, A.A. Ethics and Disclosure of Accounting, Financial and Social Information within Listed Companies-Evidence from the Bucharest Stock Exchange, Proceedings of the 2020 Basiq International Conference: New Trends in Sustainable Business and Consumption, Messina, Italy, 4-6 June 2020; Editura ASE: Bucureti, Romania, 2020; pp. 73-80.

11. Nicolescu, M.N.; Bocean, C.G.; Vărzaru, A.A. Integrative Approaches of Business Ethics, Corporate Governance and Social Responsibility, Proceedings of the 2020 Basiq International Conference: New Trends in Sustainable Business and Consumption, Messina, Italy, 4-6 June 2020; Editura ASE: Bucureti, Romania, 2020; pp. 65-72.

12. Elkington, J. Towards the Sustainable Corporation: Win-Win-Win Business Strategies for Sustainable Development. Calif. Manag. Rev. 1994, 36, 90-100. [CrossRef]

13. Slaper, T.F.; Hall, T.J. The triple bottom line: What is it and how does it work. Ind. Bus. Rev. 2011, 86, 4-8.

14. Moyo, T.; Duffett, R.; Knott, B. Environmental Factors and Stakeholders Influence on Professional Sport Organisations Engagement in Sustainable Corporate Social Responsibility: A South African Perspective. Sustainability 2020, 12, 4504. [CrossRef]

15. Moyo, T.; Davies, S.E.H.; Joubert, E. Corporate social responsibility and organisational performance of a professional football club in South Africa. Corp. Ownersh. Control 2015, 13, 610-618. [CrossRef]

16. Davies, S.E.H.; Moyo, T. Community perceptions of a CSR programme: A case study of a professional football club. Corp. Ownersh. Control 2017, 14, 197-203. [CrossRef]

17. Roy, D.P.; Graeff, T.R. Consumer attitudes toward cause-related marketing activities in professional sports. Sport Mark. Q. 2003, 12, 163-172. [CrossRef]

18. Walters, G.; Chadwick, S. Corporate citizenship in football: Delivering strategic benefits through stakeholder engagement. Acad. Manag. Rev. 2009, 32, 946-967. [CrossRef]

19. Chang, M.J.; Kang, J.H.; Ko, Y.J.; Connaughton, D.P. The effects of perceived team performance and social responsibility on pride and word-of-mouth recommendation. Sport Mark. Q. 2017, 28, 20-33. [CrossRef]

20. Babiak, K.; Wolfe, R. Determinants of corporate social responsibility in professional sport: Internal and external factors. J. Sport. Manag. 2009, 23, 717-742. [CrossRef]

21. Kim, K.; Byon, K.K.K.; Song, H.; Kim, K. Internal contributions to initiating corporate social responsibility in sport organizations. Manag. Decis. 2018, 56, 1804-1817. [CrossRef]

22. Munro, V.; Arli, D.; Rundle-Thiele, S. CSR engagement and values in a pre-emerging and emerging country context. Int. J. Emerg. Mark. 2018, 13, 1251-1272. [CrossRef]

23. Djaballah, M.; Hautbois, C.; Desbordes, M. Sponsors' CSR strategies in sport: A sensemaking approach of corporations established in France. Sport Manag. Rev. 2017, 20, 211-225. [CrossRef]

24. Servaes, H.; Tamayo, A. The impact of corporate social responsibility on firm value: The role of customer awareness. Manag. Sci. USA 2013, 59, 1045-1061. [CrossRef]

25. Lins, K.V.; Servaes, H.; Tamayo, A. Social capital, trust, and firm performance: The value of corporate social responsibility during the financial crisis. J. Financ. 2017, 72, 1785-1824. [CrossRef]

26. Branco, M.C.; Rodrigues, L.L. Corporate social responsibility and resource-based perspectives. J. Bus. Ethics 2006, 69, 111-132. [CrossRef]

27. Eveland, V.B.; Crutchfield, T.N.; Rynarzewska, A.I. Developing a consumer relationship model of corporate social performance. J. Consum. Mark. 2018, 35, 544-554. [CrossRef]

28. Stewart, B.; Smith, A. The Special Features of Sport. Ann. Leis. Res. 1999, 2, 87-99. [CrossRef]

29. Breitbarth, T.; Harris, P. The role of corporate social responsibility in the football business: Towards the development of a conceptual model. Eur. Sport Manag. Q. 2008, 8, 179-206. [CrossRef]

30. Gladwin, T.N.; Kennelly, J.J.; Krause, T.-S. Shifting Paradigms for Sustainable Development: Implications for Management Theory and Research. Acad. Manag. Rev. 1995, 20, 874-907. [CrossRef]

31. Kakabadse, N.K.; Rozuel, C.; Lee-Davies, L. Corporate social responsibility and stakeholder approach: A conceptual review. Int J. Bus. Gov. Ethics 2005, 1, 277-302. [CrossRef]

32. Kolyperas, D.; Morrow, S.; Sparks, L. Developing CSR in professional football clubs: Drivers and phases. Corp. Gov. 2015, 15, 177-195. [CrossRef]

33. Spaaij, R.; Westerbeek, H. Sport business and social capital: A contradiction in terms? Sport Soc. 2010, 13, 1356-1373. [CrossRef]

34. Inoue, Y.; Kent, A.; Lee, S. CSR and the bottom line: Analyzing the link between CSR and financial performance for professional teams. J. Sport Manag. 2011, 25, 531-549. [CrossRef]

35. Robertson, J.; Eime, R.; Westerbeek, H. Community sports clubs: Are they only about playing sport, or do they have broader health promotion and social responsibilities? Ann. Leis. Res. 2019, 22, 215-232. [CrossRef]

36. Bradish, C.; Cronin, J.J. Corporate social responsibility in sport. J. Sport Manag. 2009, 23, 691-697. [CrossRef]

37. Fifka, M.S.; Jaeger, J. CSR in professional European football: An integrative framework. Soccer Soc. 2018, 1, 1-18. [CrossRef]

38. Smith, A.C.; Westerbeek, H.M. Sport as a vehicle for deploying corporate social responsibility. J. Corp. Citizsh. 2007, 25, 43-54. [CrossRef]

39. Walters, G. Corporate social responsibility through sport. J. Corp. Citizsh. 2009, 35, 81-94. [CrossRef]

40. Zeimers, G.; Anagnostopoulos, C.; Zintz, T.; Willem, A. Organisational learning for corporate social responsibility in sport organisations. Eur. Sport Manag. Quart. 2019, 19, 80-101. [CrossRef] 
41. Rowe, K.; Karg, A.; Sherry, E. Community-oriented practice: Examining corporate social responsibility and development activities in professional sport. Sport Manag. R. 2019, 22, 363-378. [CrossRef]

42. Babiak, K.; Trendafilova, S. CSR and environmental responsibility: Motives and pressures to adopt green management practices. In Corporate Social Responsibility and Environmental Management; John Wiley \& Sons, Ltd.: Chichester, UK, 2011; Volume 18, pp. 11-24. [CrossRef]

43. Trendafilova, S.; Nguyen, S. Corporate Social Responsibility and the environment in the sport industry. In Sport Management and the Natural Environment: Theory and Practice, 1st ed.; Casper, J.M., Pfahl, M.E., Eds.; Routledge: London, UK, 2015 ; pp. 76-87.

44. Trendafilova, S.; Babiak, K.; Heinze, K. Corporate social responsibility and environmental sustainability: Why professional sport is greening the playing field. Sport Manag Rev. 2013, 16, 298-313. [CrossRef]

45. Manzini, R.; Regattieri, A.; Pham, H.; Ferrari, E. Basic Statistics and Introduction to Reliability. In Maintenance for Industrial Systems; Manzini, R., Regattieri, A., Pham, H., Ferrari, E., Eds.; Springer Series in Reliability Engineering; Springer: London, UK, 2010; pp. 87-132. [CrossRef]

46. Vărzaru, A.A.; Bocean, C.G. A Two-Stage SEM-Artificial Neural Network Analysis of Mobile Commerce and Its Drivers. J. Theor. Appl. Electron. Commer. Res. 2021, 16, 127. [CrossRef]

47. Vărzaru, A.A.; Bocean, C.G.; Cazacu, M. Rethinking Tourism Industry in Pandemic COVID-19 Period. Sustainability 2021, 13, 6956 [CrossRef]

48. Vărzaru, A.A.; Bocean, C.G.; Rotea, C.C.; Budică-Iacob, A.-F. Assessing Antecedents of Behavioral Intention to Use Mobile Technologies in E-Commerce. Electronics 2021, 10, 2231. [CrossRef]

49. Hu, L.-T.; Bentler, P.M. Fit Indices in Covariance Structure Modeling: Sensitivity to under Parameterized Model Misspecification Psych. Meth. 1998, 3, 424-453. [CrossRef]

50. Sinharay, S. An Overview of Statistics in Education. In International Encyclopedia of Education; Peterson, P., Baker, E., McGaw, B., Eds.; Elsevier: Amsterdam, The Netherlands, 2010; pp. 1-11.

51. Bocean, C.G.; Puiu, S.; Vărzaru, A.A. Paradigm Shifting-The Use of Mobile Communications at Work and the Subsequent Effects. Electronics 2021, 10, 2747. [CrossRef]

52. Civelek, M.E. Essentials of Structural Equation Modeling; Zea E-Books: Licoln, NE, USA, 2018. Available online: https:// digitalcommons.unl.edu/zeabook/64 (accessed on 11 October 2021).

53. IBM. SPSS-Neural Networks. 2012. Available online: https://www.ibm.com/downloads/cas/N7LLA2LB (accessed on 15 October 2021).

54. Hair, J.F.; Hult, G.T.M.; Ringle, C.M.; Sarstedt, M.A. Primer on Partial Least Squares Structural Equation Modeling (PLS-SEM), 2nd ed.; Sage: Thousand Oaks, CA, USA, 2017.

55. Hair, J.F.; Hollingsworth, C.L.; Randolph, A.B.; Chong, A.Y.L. An Updated and Expanded Assessment of PLS-SEM in Information Systems Research. Ind. Manag. Data Syst. 2017, 117, 442-458. [CrossRef]

56. Godfrey, P.C. Corporate social responsibility in sport: An overview and key issues. J. Sport Manag. 2009, 23, 698-716. [CrossRef]

57. Walker, M.; Kent, A. Do fans care? Assessing the influence of corporate social responsibility on consumer attitudes in the sport industry. J. Sport Manag. 2009, 23, 743-769. [CrossRef]

58. Manoli, A.E. Promoting corporate social responsibility in the Football industry. J. Promot. Manag. 2015, 21, 335-350. [CrossRef]

59. Babiak, K.; Wolfe, R. More than just a game? Corporate social responsibility and Super Bowl XL. Sport Mark. Q. 2006, 15, 214-222. [CrossRef]

60. Chen, B.H.; Chen, M.-H.; Tai, P.-N.; Hsiung, W.-C. Constructing the Corporate Social Responsibility Indicators of Professional Sport Organisation. Int. J. Bus. Adm. 2015, 6, 75-81.

61. Sheth, H.; Babiak, K. Beyond the Game: Perceptions and Practices of Corporate Social Responsibility in the Professional Sport Industry. J. Bus. Ethics 2010, 91, 433-450. [CrossRef]

62. Walters, G.; Tacon, R. Corporate Social Responsibility in European Football. Working Paper. Birkbeck, University of London, London, UK, 2011. Available online: https:/ / eprints.bbk.ac.uk/id/eprint/7618 (accessed on 7 November 2021).

63. Breitbarth, T.; Hovemann, G.; Walzel, S. Scoring strategy goals: Measuring corporate social responsibility in professional European football. Thunderbird Int. Bus. Rev. 2011, 53, 721-737. [CrossRef]

64. Brammer, S.; Millington, A. Does It Pay to Be Different? An Analysis of the Relationship Between Corporate Social and Financial Performance. Strateg. Manag. J. 2008, 29, 1325-1343. [CrossRef]

65. Moon, B.; Lee, L.W.; Oh, C.H. The impact of CSR on consumer-corporate connection and brand loyalty: A cross-cultural investigation. Int. Mark. Rev. 2015, 32, 518-539. [CrossRef]

66. Shamir, R. Mind the gap: The commodification of corporate social responsibility. Symb. Interact. 2005, 28, 229-253. [CrossRef]

67. Babiak, K. The role and relevance of corporate social responsibility in sport: A view from the top. J. Manag. Org. 2010, 16, 528-549. [CrossRef]

68. Zhang, Z.; Surujlal, J. Willingness of sport fans to participate in socially responsible community programmes of professional sport organizations. S. Afr. J. Res. Sport Phys. Educ. Recreat. 2015, 37, 185-197.

69. Moreno, A.; Capriotti, P. Communicating CSR, citizenship, and sustainability on the web. J. Commun. Manag. 2009, 13, 157-175. [CrossRef] 